\title{
Haloactinobacterium album gen. nov., sp. nov., a halophilic actinobacterium, and proposal of Ruaniaceae fam. nov.
}

\author{
Shu-Kun Tang, ${ }^{1}$ Xiao-Yang Zhi, ${ }^{1}$ Yun Wang, ${ }^{2}$ Jin-Yuan Wu, ${ }^{1}$ \\ Jae-Chan Lee, ${ }^{3}$ Chang-Jin Kim, ${ }^{3}$ Kai Lou, ${ }^{2}$ Li-Hua $X u^{1}$ and Wen-Jun Li ${ }^{1}$ \\ ${ }^{1}$ Key Laboratory for Microbial Resources of the Ministry of Education and Laboratory for \\ Conservation and Utilization of Bio-Resources, Yunnan Institute of Microbiology, \\ Yunnan University, Kunming, 650091, PR China \\ ${ }^{2}$ Xinjiang Institute of Microbiology, Xinjiang Academy of Agricultural Science, Urumqi, Xinjiang, \\ 830091, PR China \\ ${ }^{3}$ Functional Metabolite Research Center KRIBB, 52 Eoeun-dong, Yuseong gu, Daejeon 305-806, \\ Republic of Korea
}

Correspondence

Wen-Jun Li

wjli@ynu.edu.cn or

liact@hotmail.com

\begin{abstract}
A Gram-staining-positive, facultatively anaerobic, non-motile and moderately halophilic

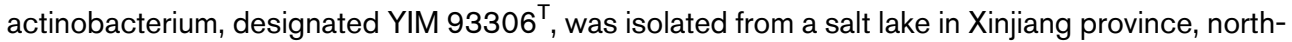
west China, and subjected to a polyphasic taxonomic study. Strain YIM 93306 ${ }^{\top}$ grew in the presence of $2-16 \%(w / v) ~ N a C l$ and did not grow without $\mathrm{NaCl}$. The peptidoglycan type was $\mathrm{A} 4 \alpha$ with an L-Lys-L-Glu interpeptide bridge. The whole-cell sugars were glucosamine, arabinose, mannose and two unknown sugars. The predominant menaquinone was $\mathrm{MK}-8\left(\mathrm{H}_{4}\right)$. The major fatty acids were iso- $\mathrm{C}_{15: 0}$, anteiso- $\mathrm{C}_{15: 0}$ and anteiso- $\mathrm{C}_{17: 0}$. The polar lipids comprised diphosphatidylglycerol, phosphatidylglycerol, phosphatidylinositol, one unknown phosphoglycolipid and one unknown phospholipid. The DNA G +C content was $68.3 \mathrm{~mol} \%$. Phylogenetic analysis based on 16S rRNA gene sequences revealed that strain YIM $93306^{\top}$ fell within the radius of the suborder Micrococcineae. Its closest phylogenetic neighbour was the type strain of Ruania albidiflava (AS $4.3142^{\top} ; 96.2 \% 16$ S rRNA gene sequence similarity), the sole recognized species of the genus Ruania. Sequence similarities between strain YIM $93306^{\top}$ and members of other genera of the suborder Micrococcineae were $<95.2 \%$. On the basis of phylogenetic analysis, phenotypic characteristics and chemotaxonomic differences, a novel genus and species, Haloactinobacterium album gen. nov., sp. nov., is proposed. The type strain of the species is YIM 93306 ${ }^{\top}$ (=DSM $21368^{\top}=$ KCTC $19413^{\top}=$ CCTCC AB 208069 ${ }^{\top}$ ). Based on phylogenetic characteristics and 16S rRNA gene signature nucleotide patterns, the genera Ruania and Haloactinobacterium gen. nov. are proposed to belong to a novel family, Ruaniaceae fam. nov.
\end{abstract}

The suborder Micrococcineae was proposed by Stackebrandt et al. (1997) based on phylogenetic and signature nucleotide analysis of the 16S rRNA gene sequence. At the time of writing, the suborder Micrococcineae comprises 15 families: Beutenbergiaceae (Zhi et al., 2009), Bogoriellaceae (Stackebrandt \& Schumann, 2000; Zhi et al., 2009), Brevibacteriaceae (Breed, 1953; Stackebrandt et al., 1997; Stackebrandt \& Schumann, 2000; Zhi et al., 2009), Cellulomonadaceae (Stackebrandt \& Prauser, 1991; Stackebrandt et al., 1997; Stackebrandt \& Schumann 2000; Zhi et al., 2009),

The GenBank/EMBL/DDBJ accession number for the 16S rRNA gene

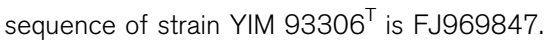

Dermabacteraceae (Stackebrandt et al., 1997; Zhi et al., 2009), Dermacoccaceae (Stackebrandt \& Schumann, 2000; Zhi et al., 2009), Dermatophilaceae (Austwick, 1958; Stackebrandt et al., 1997; Stackebrandt \& Schumann 2000; Zhi et al., 2009), Intrasporangiaceae (Stackebrandt et al., 1997; Stackebrandt \& Schumann 2000; Zhi et al., 2009), Jonesiaceae (Stackebrandt et al., 1997; Zhi et al., 2009), Microbacteriaceae (Park et al., 1993; Stackebrandt et al., 1997; Zhi et al., 2009), Micrococcaceae (Pribram, 1929; Stackebrandt et al., 1997; Zhi et al., 2009), Promicromonosporaceae (Stackebrandt et al., 1997; Zhi et al., 2009), Rarobacteraceae (Stackebrandt \& Schumann, 2000; Zhi et al., 2009), Sanguibacteraceae (Stackebrandt \& Schumann, 2000; Zhi et al., 2009) and Yaniellaceae (Li et al., 
2005, 2008). The genus Ruania (Gu et al., 2007) has not been classified in a family. The pattern of 16S rRNA gene signature nucleotides of the suborder Micrococcineae consists of nucleotides at positions 127:234 (A-U), $598: 640$ (U-G), 657:749 (U-A), 953:1228 (G-C), 986:1219 (A-U), 987:1218 (A-U) and 1362 (A) (Zhi et al., 2009). In this paper, we report the characterization of strain YIM $93306^{\mathrm{T}}$ and propose Haloactinobacterium album gen. nov., sp. nov. A new family, Ruaniaceae fam. nov., is proposed to accommodate the genera Ruania and Haloactinobacterium gen. nov.

Strain YIM $93306^{\mathrm{T}}$ was isolated from a soil sample collected from Qijiaojing Lake, which is a salt lake in Xinjiang province, north-west China $\left(43^{\circ} 27^{\prime} \mathrm{N} 91^{\circ} 29^{\prime} \mathrm{E}\right)$, after 3 weeks incubation at $37{ }^{\circ} \mathrm{C}$ on glucose-tryptoneyeast (GTY) agar [containing $\left(1^{-1}\right): 1.0 \mathrm{~g}$ glucose, $0.5 \mathrm{~g}$ tryptone, 2.0 g yeast extract, $1.0 \mathrm{~g} \mathrm{CaCl}_{2}, 15.0 \mathrm{~g}$ agar; final $\mathrm{pH}$ not adjusted] supplemented with $10 \%(\mathrm{w} / \mathrm{v}) \mathrm{NaCl}$. $\mathrm{NaCl}$ was sterilized separately before being added to the medium. Strain YIM $93306^{\mathrm{T}}$ was maintained on GTY agar slants at $4{ }^{\circ} \mathrm{C}$ and in $20 \%(\mathrm{v} / \mathrm{v})$ glycerol suspensions at $-20{ }^{\circ} \mathrm{C}$. Biomass for chemical and molecular studies was obtained by cultivation in GTY broth supplemented with $10 \% \mathrm{NaCl}$ at $37{ }^{\circ} \mathrm{C}$ and 150 r.p.m. for about 1 week.

Cell morphology was determined with cultures grown for $6,12,24,48$ and $72 \mathrm{~h}$ on GTY agar supplemented with $10 \% \mathrm{NaCl}$ at $37{ }^{\circ} \mathrm{C}$. The Gram reaction was determined by Gram staining and the KOH lysis test (Cerny, 1978). Cell motility was confirmed by the development of turbidity throughout a tube containing semisolid medium (Leifson, 1960). Morphological characteristics were observed by light microscopy (model BH2; Olympus) and by transmission electron microscopy (model H-800; Hitachi). Growth was tested at $5-55{ }^{\circ} \mathrm{C}$ on GTY agar supplemented with $10 \%$ $\mathrm{NaCl}$ at intervals of $5{ }^{\circ} \mathrm{C}$. Tolerance to $0-20 \%(\mathrm{w} / \mathrm{v}) \mathrm{NaCl}$ (in intervals of $1 \%$ ) was tested using GTY agar as the basal medium. Growth at $\mathrm{pH} 4.0-10.0$ (in intervals of $1 \mathrm{pH}$ unit) was tested on GTY agar supplemented with $10 \%$ $\mathrm{NaCl}$, with the $\mathrm{pH}$ adjusted using the following buffer systems: $0.1 \mathrm{M}$ citric acid/0.1 M sodium citrate $(\mathrm{pH} 4.0$ 5.0); $0.1 \mathrm{M} \mathrm{KH}_{2} \mathrm{PO}_{4} / 0.1 \mathrm{M} \mathrm{NaOH}$ (pH 6.0-8.0); and $0.1 \mathrm{M} \mathrm{NaHCO} / 0.1 \mathrm{M} \mathrm{Na}_{2} \mathrm{CO}_{3}$ (pH 9.0-10.0). Catalase activity was determined by production of bubbles after the addition of a drop of $3 \% \mathrm{H}_{2} \mathrm{O}_{2}$. Oxidase activity was observed by oxidation of tetramethyl-p-phenylenediamine. Methyl red and Voges-Proskauer tests and hydrolysis of aesculin, casein, cellulose, chitin, dextrin, DNA, gelatin, starch, urea and Tweens 20, 40, 60 and 80 were determined as described by Cowan \& Steel (1965). Oxidation of 95 different substrates was tested using Biolog GP2 MicroPlates (Biolog). Enzyme activity and acid production from carbohydrates were determined using API 20E, API ZYM and API 50CH test panels (bioMérieux) according to the manufacturer's instructions. Anaerobic growth was determined using the GasPak anaerobic system (BBL) according to the manufacturer's instructions. The morphological, cultural and physiological properties of strain
YIM $93306^{\mathrm{T}}$ are given in the species description and in Table 1.

The peptidoglycan structure of the cell wall of strain YIM $93306^{\mathrm{T}}$ was determined by using established procedures (Schleifer \& Kandler, 1972; Schleifer, 1985; MacKenzie, 1987). Whole-cell sugars were detected by HPLC after precolumn derivatization with 1-phenyl-3-methyl-5-pyrazolone (Tang et al., 2009). Polar lipids were extracted, examined by two-dimensional TLC and identified using described procedures (Minnikin et al., 1984). Menaquinones were isolated according to Minnikin et al. (1984). The purified menaquinones were dissolved in acetone and separated by atmospheric-pressure photoionization-LCMS (Tang et al., 2008). For fatty acid analysis, cells of strain YIM $93306^{\mathrm{T}}$ were cultured on tryptic soy agar (TSA; Difco) supplemented with $10 \% \mathrm{NaCl}$ at $37{ }^{\circ} \mathrm{C}$ for 4 days. Cellular fatty acid analysis was performed as described by Sasser (1990) using the Microbial Identification System (MIDI). Genomic DNA of strain YIM $93306^{\mathrm{T}}$ for the determination of $\mathrm{G}+\mathrm{C}$ content was prepared according to the method of Marmur (1961). The G+C content of the DNA was determined by reversed-phase HPLC of nucleosides according to Mesbah et al. (1989).

The peptidoglycan of strain YIM $93306^{\mathrm{T}}$ contained Ala, Glu and Lys in a molar ratio of $1.5: 1.6: 1$. Enantiomeric analysis of cell-wall diamino acids resulted in the detection of D-Ala, L-Ala, D-Glu, L-Glu and L-Lys. The peptides L-Ala $\leftarrow$ D-Glu and L-Lys $\leftarrow \mathrm{D}$-Ala were detected in the partial hydrolysate $\left(4 \mathrm{M} \mathrm{HCl}, 100{ }^{\circ} \mathrm{C}, 16 \mathrm{~h}\right.$ ) of the peptidoglycan. Glutamic acid was detected as the $\mathrm{N}$-terminus of the interpeptide bridge. From these results, it was concluded that strain YIM $93306^{\mathrm{T}}$ contained peptidoglycan type A4 $\alpha$ with an L-Lys-L-Glu interpeptide bridge (DSMZ, 2001). The whole-cell sugars were glucosamine $(48.7 \%)$, arabinose $(28.3 \%)$ and mannose $(12.0 \%)$, and there were minor amounts of two unknown sugars (8.0 and $3.1 \%$, respectively). The polar lipids comprised diphosphatidylglycerol, phosphatidylglycerol, phosphatidylinositol, one unknown phosphoglycolipid and one unknown phospholipid. The predominant menaquinone was MK-8( $\left.\mathrm{H}_{4}\right)(88.1 \%)$; minor amounts of MK-8 (3.1\%), MK- $8\left(\mathrm{H}_{2}\right)(4.2 \%)$, MK- $8\left(\mathrm{H}_{6}\right)(1.5 \%)$ and MK$9\left(\mathrm{H}_{4}\right)(2.8 \%)$ were also detected. Strain YIM $93306^{\mathrm{T}}$ had a cellular fatty acid profile that contained major amounts of branched fatty acids and minor amounts of straight fatty acids: anteiso- $\mathrm{C}_{15: 0}(34.4 \%)$, iso- $\mathrm{C}_{15: 0}(33.1 \%)$, anteiso$\mathrm{C}_{17: 0}(14.8 \%), \mathrm{C}_{17: 0}(8.7 \%)$, iso- $\mathrm{C}_{16: 0}(2.3 \%), \mathrm{C}_{16: 0}$ $(2.1 \%)$, iso- $\mathrm{C}_{15: 0}$ 3-OH $(0.9 \%)$ and iso- $\mathrm{C}_{15: 0} \quad 2-\mathrm{OH}$ $(0.9 \%)$; other fatty acids were present in amounts less than $0.5 \%$. The $\mathrm{G}+\mathrm{C}$ content of the DNA was $68.3 \mathrm{~mol} \%$.

Extraction of genomic DNA and PCR amplification of the $16 \mathrm{~S}$ rRNA gene were performed as described by Li et al. (2007). Multiple alignments with sequences from the most closely related members of the suborder Micrococcineae and calculations of sequence similarities were performed with the EzTaxon server 2.0 (Chun et al., 2007). Phylogenetic analyses were performed by using three tree-making 
Table 1. Differential morphological, phenotypic and chemotaxonomic characters of strain YIM $93306^{\top}$ and the type strain of the only species of the genus Ruania

Strains: 1, Haloactinobacterium album YIM $93306^{\mathrm{T}}$; 2, Ruania albidiflava AS $4.3142^{\mathrm{T}}$. Data are from this study and $\mathrm{Gu}$ et al. (2007). DPG, Diphosphatidylglycerol; GL, glycolipid; PG, phosphatidylglycerol; PGL, phosphoglycolipid; PI, phosphatidylinositol; PL, phospholipid; +, positive; -, negative.

\begin{tabular}{|c|c|c|}
\hline Characteristic & 1 & 2 \\
\hline Cell morphology & Rod & Coccoid \\
\hline Colony colour & Cream white & Pale yellow \\
\hline Facultative anaerobe & + & - \\
\hline \multicolumn{3}{|l|}{ Growth with: } \\
\hline $0 \% \mathrm{NaCl}$ & - & + \\
\hline $15 \% \mathrm{NaCl}$ & + & - \\
\hline \multicolumn{3}{|l|}{ Range for growth } \\
\hline $\mathrm{pH}$ & $6-10$ & $5.5-12.5$ \\
\hline Temperature $\left({ }^{\circ} \mathrm{C}\right)$ & $10-40$ & $20-37$ \\
\hline Methyl red test & - & + \\
\hline Nitrate reduction & - & + \\
\hline \multicolumn{3}{|l|}{ Enzymes (API ZYM) } \\
\hline Esterase (C4) & + & - \\
\hline Alkaline phosphatase & - & + \\
\hline Leucine arylamidase & - & + \\
\hline Valine arylamidase & - & + \\
\hline Naphthol-AS-BI- & - & + \\
\hline \multicolumn{3}{|l|}{ phosphohydrolase } \\
\hline$\alpha$-Glucosidase & - & + \\
\hline$\alpha$-Galactosidase & - & + \\
\hline$\alpha$-Fucosidase & - & + \\
\hline \multicolumn{3}{|c|}{ Acid production (API $50 \mathrm{CH}$ ) from: } \\
\hline Arbutin & - & + \\
\hline D-Adonitol & + & - \\
\hline Cellobiose & + & - \\
\hline D-Galactose & + & - \\
\hline D-Glucose & + & - \\
\hline D-Lyxose & - & + \\
\hline D-Mannose & + & - \\
\hline Turanose & + & - \\
\hline D-Tagatose & + & - \\
\hline Erythritol & + & - \\
\hline Glycerol & + & - \\
\hline$N$-Acetylglucosamine & + & - \\
\hline Interpeptide bridge $(\mathrm{A} 4 \alpha)$ & L-Lys-L-Glu & L-Lys-Gly-L-Glu-L-Glu \\
\hline Whole-cell sugars & $\begin{array}{l}\text { Glucosamine, arabinose, } \\
\text { mannose, two unknown sugars }\end{array}$ & Galactose, glucose \\
\hline Polar lipids & DPG, PG, PGL, PI, PL & DPG, PG, GL \\
\hline \multicolumn{3}{|l|}{ Major fatty acids $(>10 \%)$} \\
\hline anteiso- $\mathrm{C}_{15: 0}$ & 34.4 & 37.3 \\
\hline iso- $\mathrm{C}_{15: 0}$ & 33.1 & - \\
\hline iso- $\mathrm{C}_{16: 0}$ & - & 14.3 \\
\hline anteiso- $\mathrm{C}_{17: 0}$ & 14.8 & 14.7 \\
\hline $\begin{array}{l}\text { DNA G }+C \text { content } \\
(\mathrm{mol} \%)\end{array}$ & 68.3 & 70.0 \\
\hline
\end{tabular}

algorithms: neighbour joining (Saitou \& Nei, 1987), maximum likelihood (Felsenstein, 1981) and maximum parsimony (Fitch, 1971). A phylogenetic tree was constructed using the neighbour-joining method from $K_{\text {nuc }}$ values (Kimura, 1980) using MEGA version 4.0 (Tamura et al., 2007). The topology of the phylogenetic tree was evaluated by the bootstrap resampling method of Felsenstein (1985) with 1000 replicates. 
An almost-complete 16S rRNA gene sequence (1524 bp) was determined for strain YIM $93306^{\mathrm{T}}$. Phylogenetic analysis based on 16S rRNA gene sequences revealed that strain YIM $93306^{\mathrm{T}}$ fell within the radius of the suborder Micrococcineae and that its closest phylogenetic neighbour was Ruania albidiflava AS $4.3142^{\mathrm{T}}$ (96.2\% sequence similarity), the type strain of the sole recognized species of the genus Ruania.
Sequence similarities between strain YIM $93306^{\mathrm{T}}$ and members of other genera of the suborder Micrococcineae were $<95.2 \%$. In the phylogenetic tree based on the neighbourjoining algorithm, strain YIM $93306^{\mathrm{T}}$ and $R$. albidiflava AS $4.3142^{\mathrm{T}}$ formed two branches with a high bootstrap value $(99 \%)$ in a distinct clade. This relationship was supported by the other tree-making methods used in this study (Fig. 1).

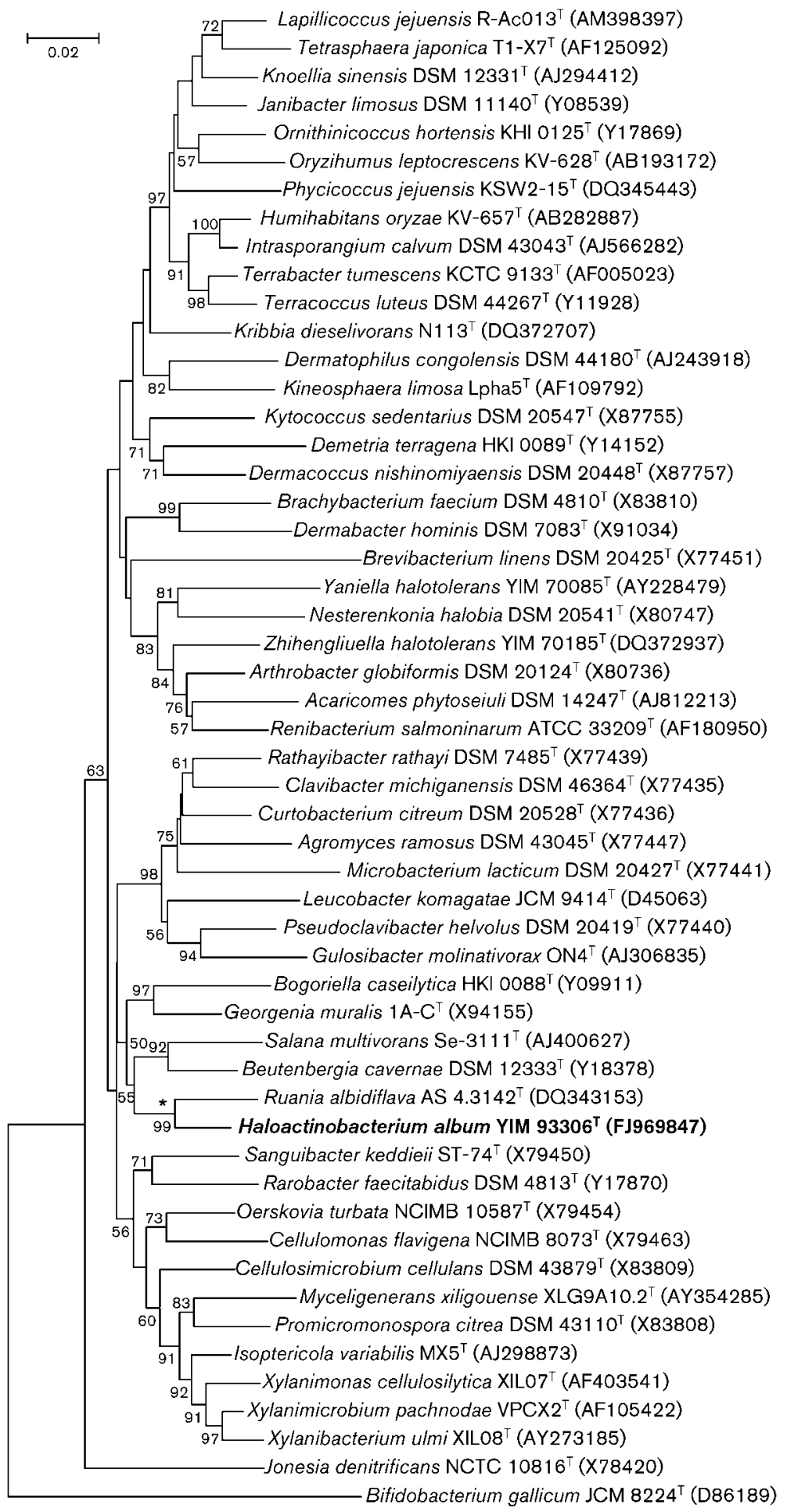

Fig. 1. Phylogenetic dendrogram obtained by distance-matrix analysis of 16S rRNA gene sequences, showing the positions of strain YIM $93306^{\top}$ and type strains of type species of genera in the suborder Micrococcineae. An asterisk indicates that the corresponding node was also recovered in the trees constructed with the maximum-likelihood and maximumparsimony algorithms. Bootstrap values ( $>50 \%$ ) based on 1000 resampled datasets are shown at branch nodes. Bifidobacterium gallicum JCM $8224^{\top}$ was used as an outgroup. Bar, 0.02 substitutions per nucleotide position. 
All of the above data confirmed that the new isolate should be assigned to the suborder Micrococcineae. Strain YIM $93306^{\mathrm{T}}$ formed a monophyletic branch at the periphery of the evolutionary radiation occupied by the genus Ruania. Although strain YIM $93306^{\mathrm{T}}$ was similar to $R$. albidiflava AS $4.3142^{\mathrm{T}}$ by having $\mathrm{MK}-8\left(\mathrm{H}_{4}\right)$ as the predominant menaquinone and $\mathrm{A} 4 \alpha$ as the peptidoglycan type, it was different in some morphological and physiological properties (Table 1). Strain YIM $93306^{\mathrm{T}}$ was a halophilic bacterium and it grew with $16 \% \mathrm{NaCl}$ but not without $\mathrm{NaCl}$, whereas $R$. albidiflava AS $4.3142^{\mathrm{T}}$, as a nonhalophilic actinobacterium, grew well without $\mathrm{NaCl}$ but not with $15 \% \mathrm{NaCl}$. Also, strain YIM $93306^{\mathrm{T}}$ exhibited some chemotaxonomic differences from $R$. albidiflava AS $4.3142^{\mathrm{T}}$ (Table 1). For instance, strain YIM $93306^{\mathrm{T}}$ contained glucosamine, arabinose, mannose and two unknown sugars as whole-cell sugars and L-Lys-L-Glu as the interpeptide bridge of the peptidoglycan, whereas $R$. albidiflava AS $4.3142^{\mathrm{T}}$ contained galactose and glucose as the whole-cell sugars and L-Lys-Gly-L-Glu-L-Glu as the interpeptide bridge. Also, as well as anteiso- $\mathrm{C}_{15: 0}$ and anteiso- $\mathrm{C}_{17: 0}$ as major fatty acids, strain YIM $93306^{\mathrm{T}}$ contained iso- $\mathrm{C}_{15: 0}$ and $R$. albidiflava AS $4.3142^{\mathrm{T}}$ contained iso- $\mathrm{C}_{16: 0}$ as the additional major fatty acid. Therefore, on the basis of phenotypic, chemotaxonomic and phylogenetic differentiation of strain YIM $93306^{\mathrm{T}}$ from its closest neighbour, $R$. albidiflava AS $4.3142^{\mathrm{T}}$, we propose that strain YIM $93306^{\mathrm{T}}$ represents a novel species in a new genus, Haloactinobacterium album gen. nov., sp. nov.

Representatives of the 15 described families in the suborder Micrococcineae showed 16S rRNA gene sequence similarities to R. albidiflava AS $4.3142^{\mathrm{T}}$ and strain YIM $93306^{\mathrm{T}}$ of between 92.0 and $95.2 \%$, and R. albidiflava AS $4.3142^{\mathrm{T}}$ and strain YIM $93306^{\mathrm{T}}$ formed a deep branch that was clearly distinguished from the families of the suborder Micrococcineae. Thus, although $R$. albidiflava AS $4.3142^{\mathrm{T}}$ and strain YIM $93306^{\mathrm{T}}$ clearly belong to the suborder Micrococcineae, they do not belong to any of the described families within the suborder. The 16S rRNA gene sequences of representatives of the 15 families of the suborder Micrococcineae (Zhi et al., 2009), R. albidiflava AS $4.3142^{\mathrm{T}}$ and strain YIM $93306^{\mathrm{T}}$ were scanned for the signature nucleotides of the suborder Micrococcineae. We only found one difference between $R$. albidiflava AS $4.3142^{\mathrm{T}}$ and strain YIM $93306^{\mathrm{T}}$, at position $602: 636$, where $C-G$ was found in strain YIM $93306^{\mathrm{T}}$ and G-U was found in R. albidiflava AS $4.3142^{\mathrm{T}}$ (Table 2). There was only one position for $R$. albidiflava AS $4.3142^{\mathrm{T}}$ and strain YIM $93306^{\mathrm{T}}$ that was unique among the family of the suborder Micrococcineae: position $444: 490$, where C-U was found in $R$. albidiflava AS $4.3142^{\mathrm{T}}$ and strain YIM $93306^{\mathrm{T}}$; all of the other signatures studied were found in at least one other family. However, strain YIM $93306^{\mathrm{T}}$ and R. albidiflava AS $4.3142^{\mathrm{T}}$

Table 2. Patterns of $16 \mathrm{~S}$ rRNA gene signature nucleotides detected in the family Ruaniaceae and the defined families of the suborder Micrococcineae

Families: 1, Ruaniaceae; 2, Beutenbergiaceae; 3, Bogoriellaceae; 4, Brevibacteriaceae; 5, Cellulomonadaceae; 6, Dermabacteraceae; 7, Dermacoccaceae; 8, Dermatophilaceae; 9, Intrasporangiaceae; 10, Jonesiaceae; 11, Microbacteriaceae; 12, Micrococcaceae; 13, Promicromonosporaceae; 14, Rarobacteraceae; 15, Sanguibacteraceae; 16, Yaniellaceae. Data for columns 2-16 were taken from Zhi et al. (2009).

\begin{tabular}{|c|c|c|c|c|c|c|c|c|c|c|c|c|c|c|c|c|}
\hline Position & 1 & 2 & 3 & 4 & 5 & 6 & 7 & 8 & 9 & 10 & 11 & 12 & 13 & 14 & 15 & 16 \\
\hline 120 & A & A & A & A & A & A & A & A & A & A & A & W & A & A & A & $\mathrm{U}$ \\
\hline $131: 231$ & $A-G$ & $\mathrm{C}-\mathrm{G}$ & $A-G$ & $\mathrm{C}-\mathrm{G}$ & $\mathrm{C}-\mathrm{G}$ & $\mathrm{C}-\mathrm{G}$ & $A-G$ & $\mathrm{Y}-\mathrm{K}$ & $A-G$ & $A-G$ & G-R & $\mathrm{C}-\mathrm{G}$ & $A-G$ & $\mathrm{C}-\mathrm{G}$ & $\mathrm{C}-\mathrm{G}$ & $A-G$ \\
\hline $342: 347$ & $\mathrm{C}-\mathrm{G}$ & $\mathrm{C}-\mathrm{G}$ & U-G & $\mathrm{C}-\mathrm{G}$ & $\mathrm{C}-\mathrm{G}$ & $C-G$ & $\mathrm{C}-\mathrm{G}$ & $\mathrm{C}-\mathrm{G}$ & $\mathrm{C}-\mathrm{G}$ & $\mathrm{C}-\mathrm{G}$ & $\mathrm{C}-\mathrm{G}$ & $\mathrm{C}-\mathrm{G}$ & $C-G$ & $\mathrm{C}-\mathrm{G}$ & $\mathrm{C}-\mathrm{G}$ & $\mathrm{C}-\mathrm{G}$ \\
\hline $444: 490$ & $\mathrm{C}-\mathrm{U}$ & $\mathrm{A}-\mathrm{U}$ & $\mathrm{A}-\mathrm{U}$ & $\mathrm{A}-\mathrm{U}$ & $\mathrm{A}-\mathrm{U}$ & $\mathrm{A}-\mathrm{U}$ & $\mathrm{A}-\mathrm{U}$ & $\mathrm{A}-\mathrm{U}$ & $\mathrm{A}-\mathrm{U}$ & $\mathrm{A}-\mathrm{U}$ & $\mathrm{A}-\mathrm{U}$ & $\mathrm{A}-\mathrm{U}$ & $\mathrm{A}-\mathrm{U}$ & $\mathrm{A}-\mathrm{U}$ & $\mathrm{A}-\mathrm{U}$ & $\mathrm{U}-\mathrm{U}$ \\
\hline $580: 761$ & $\mathrm{C}-\mathrm{G}$ & $\mathrm{C}-\mathrm{G}$ & C-A & $\mathrm{C}-\mathrm{G}$ & $\mathrm{C}-\mathrm{G}$ & $\mathrm{U}-\mathrm{A}$ & $\mathrm{U}-\mathrm{A}$ & $\mathrm{U}-\mathrm{A}$ & U-A & $C-G$ & $\mathrm{C}-\mathrm{G}$ & $C-G$ & $C-G$ & $\mathrm{C}-\mathrm{G}$ & $\mathrm{C}-\mathrm{G}$ & $\mathrm{C}-\mathrm{G}$ \\
\hline $670: 736$ & $\mathrm{~A}-\mathrm{U}$ & $\mathrm{A}-\mathrm{U}$ & $\mathrm{A}-\mathrm{U}$ & U-A & $\mathrm{A}-\mathrm{U}$ & $\mathrm{A}-\mathrm{U}$ & $\mathrm{A}-\mathrm{U}$ & $\mathrm{A}-\mathrm{U}$ & $\mathrm{A}-\mathrm{U}$ & $\mathrm{A}-\mathrm{U}$ & $\mathrm{A}-\mathrm{U}$ & $\mathrm{A}-\mathrm{U}$ & $\mathrm{A}-\mathrm{U}$ & $\mathrm{A}-\mathrm{U}$ & $\mathrm{A}-\mathrm{U}$ & $\mathrm{A}-\mathrm{U}$ \\
\hline $822: 878$ & $\mathrm{G}-\mathrm{C}$ & G-C & $\mathrm{G}-\mathrm{C}$ & $\mathrm{G}-\mathrm{C}$ & $\mathrm{G}-\mathrm{C}$ & $\mathrm{G}-\mathrm{C}$ & $\mathrm{G}-\mathrm{C}$ & G-C & G-C & $\mathrm{U}-\mathrm{C}$ & $\mathrm{G}-\mathrm{C}$ & $\mathrm{G}-\mathrm{C}$ & $\mathrm{G}-\mathrm{C}$ & $\mathrm{G}-\mathrm{C}$ & $\mathrm{G}-\mathrm{C}$ & $\mathrm{G}-\mathrm{C}$ \\
\hline $823: 877$ & $\mathrm{G}-\mathrm{C}$ & $\mathrm{G}-\mathrm{C}$ & $\mathrm{G}-\mathrm{C}$ & $\mathrm{G}-\mathrm{C}$ & $\mathrm{G}-\mathrm{C}$ & $\mathrm{G}-\mathrm{C}$ & $\mathrm{G}-\mathrm{C}$ & $\mathrm{G}-\mathrm{C}$ & $\mathrm{G}-\mathrm{C}$ & $A-G$ & $\mathrm{G}-\mathrm{C}$ & $\mathrm{G}-\mathrm{C}$ & $\mathrm{G}-\mathrm{C}$ & $\mathrm{G}-\mathrm{C}$ & $\mathrm{G}-\mathrm{C}$ & $\mathrm{G}-\mathrm{C}$ \\
\hline $826: 874$ & $\mathrm{C}-\mathrm{G}$ & $\mathrm{C}-\mathrm{G}$ & $\mathrm{C}-\mathrm{G}$ & $\mathrm{C}-\mathrm{G}$ & $\mathrm{C}-\mathrm{G}$ & $\mathrm{C}-\mathrm{G}$ & $\mathrm{C}-\mathrm{G}$ & $\mathrm{C}-\mathrm{G}$ & $\mathrm{C}-\mathrm{G}$ & U-G & $\mathrm{C}-\mathrm{G}$ & $\mathrm{C}-\mathrm{G}$ & C-G & C-G & $\mathrm{C}-\mathrm{G}$ & $\mathrm{C}-\mathrm{G}$ \\
\hline 827 & $\mathrm{U}$ & U & U & U & U & $\mathrm{U}$ & U & $\mathrm{U}$ & $\mathrm{U}$ & $\mathrm{G}$ & U & $\mathrm{U}$ & U & $\mathrm{U}$ & U & $\mathrm{U}$ \\
\hline 843 & $\mathrm{U}$ & $\mathrm{U}$ & C & C & $\mathrm{U}$ & C & C & $\mathrm{U}$ & $\mathrm{U}$ & C & C & $\mathrm{C}$ & $\mathrm{U}$ & $\mathrm{U}$ & $\mathrm{C}$ & $\mathrm{U}$ \\
\hline 1145 & G & G & G & A & G & G & G & G & G & G & $\mathrm{R}$ & G & G & G & G & G \\
\hline $1309: 1328$ & $\mathrm{G}-\mathrm{C}$ & $\mathrm{G}-\mathrm{C}$ & $\mathrm{A}-\mathrm{U}$ & $\mathrm{G}-\mathrm{C}$ & $\mathrm{G}-\mathrm{C}$ & $\mathrm{G}-\mathrm{U}$ & $\mathrm{G}-\mathrm{C}$ & $\mathrm{G}-\mathrm{C}$ & $\mathrm{G}-\mathrm{C}$ & $\mathrm{G}-\mathrm{C}$ & $\mathrm{G}-\mathrm{C}$ & $\mathrm{G}-\mathrm{C}$ & $\mathrm{G}-\mathrm{C}$ & $\mathrm{G}-\mathrm{C}$ & $\mathrm{G}-\mathrm{C}$ & $\mathrm{G}-\mathrm{C}$ \\
\hline 1361 & G & G & G & G & G & G & G & G & C & G & G & G & G & G & G & G \\
\hline 1383 & $\mathrm{U}$ & $\mathrm{U}$ & $\mathrm{U}$ & $\mathrm{C}$ & $\mathrm{Y}$ & C & $\mathrm{C}$ & $\mathrm{C}$ & $\mathrm{C}$ & $\mathrm{C}$ & $\mathrm{C}$ & C & C & $\mathrm{C}$ & C & $\mathrm{C}$ \\
\hline
\end{tabular}


had a unique combination of $16 \mathrm{~S}$ rRNA gene signature nucleotides compared with those for the 15 known families of the suborder Micrococcineae (Table 2). Higher hierarchical taxa in the class Actinobacteria should be based mainly on $16 \mathrm{~S}$ rRNA gene signature nucleotide patterns and phylogenetic criteria (Stackebrandt et al., 1997; Zhi et al., 2009). Accordingly, it has been shown that the genus Ruania and strain YIM $93306^{\mathrm{T}}$ are closely related phylogenetically and distinct from other families in the suborder Micrococcineae. Thus, Ruaniaceae fam. nov. is proposed to accommodate the genera Ruania and Haloactinobacterium gen. nov.

\section{Description of Ruaniaceae fam. nov.}

Ruaniaceae (Ru.a.ni.a'ce.ae. N.L. fem. n. Ruania type genus of the family; -aceae ending to denote a family; N.L. fem. pl. n. Ruaniaceae the Ruania family).

The family contains the type genus, Ruania Gu et al. 2007, as well as the genus Haloactinobacterium gen. nov. The pattern of $16 \mathrm{~S}$ rRNA gene signature nucleotides is shown in Table 2.

\section{Description of Haloactinobacterium gen. nov.}

Haloactinobacterium (Ha.lo.ac.ti.no.bac.te'ri.um. Gr. n. hals, halos salt; Gr. n. actis, actinos a ray; L. neut n. bacterium a rod; N.L. neut. n. Haloactinobacterium a halophilic actinobacterium).

Cells are aerobic, Gram-staining-positive, non-motile and moderately halophilic short rods $(0.3-0.4 \times 0.6-0.7 \mu \mathrm{m})$. No rod-coccus life cycle. Facultatively anaerobic in the presence of $\mathrm{KNO}_{3}$. Does not form endospores. The peptidoglycan is type A4 $\alpha$ with L-Lys-L-Glu as the interpeptide bridge. The whole-cell sugars are glucosamine, arabinose, mannose and two unknown sugars. The predominant menaquinone is $\mathrm{MK}-8\left(\mathrm{H}_{4}\right)$. The polar lipids are diphosphatidylglycerol, phosphatidylglycerol, phosphatidylinositol, one unknown phosphoglycolipid and one unknown phospholipid. The major fatty acids are anteiso- $\mathrm{C}_{15: 0}$, iso- $\mathrm{C}_{15: 0}$ and anteiso- $\mathrm{C}_{17: 0}$. The $\mathrm{G}+\mathrm{C}$ content of DNA is $68-69 \mathrm{~mol} \%$. The type species is Haloactinobacterium album.

\section{Description of Haloactinobacterium album sp. nov.}

Haloactinobacterium album (al'bum. L. neut. adj. album white).

Exhibits the following properties in addition to those given in the genus description. Colonies are creamy white, circular, smooth, opaque and non-pigmented on GTY agar supplemented with $10 \% \mathrm{NaCl}$. Grows at $10-40{ }^{\circ} \mathrm{C}$ (optimum $37^{\circ} \mathrm{C}$ ), at $\mathrm{pH}$ 6.0-10.0 (optimum $\mathrm{pH}$ 7.0-8.0) and with $2-16 \%$ (w/v) $\mathrm{NaCl}$ (optimum $7-10 \% \mathrm{NaCl}$ ). Catalase-positive and oxidase-negative. Methyl red and Voges-Proskauer tests are negative. Cellulose and aesculin are hydrolysed, but gelatin, casein, dextrin, starch, DNA, chitin, urea and Tweens 20, 40, 60 and 80 are not. Reduction of nitrate and production of $\mathrm{H}_{2} \mathrm{~S}$, melanin and indole are negative. With API ZYM, positive for esterase $(\mathrm{C} 4)$, esterase lipase (C8), cystine arylamidase, $\beta$-galactosidase, $\beta$-glucosidase, $\alpha$-mannosidase and $N$-acetyl- $\beta$-glucosaminidase, but negative for lipase (C14), alkaline phosphatase, leucine arylamidase, valine arylamidase, trypsin, $\alpha$-chymotrypsin, naphthol-AS-BI-phosphohydrolase, $\alpha$-fucosidase, $\alpha$-galactosidase, $\alpha$-glucosidase and $\beta$ glucuronidase. With GP2 MicroPlates, oxidizes L-arabinose, D-fructose, L-fucose, D-galactose, $\alpha$-D-glucose, maltose, D-mannose, D-psicose, D-ribose, sucrose, D-xylose, methyl $\beta$-D-galactoside, pyruvic acid, pyruvic acid methyl ester, DL- $\alpha$-glycerol phosphate, DL-lactic acid, acetic acid, glycerol and amygdalin. Produces acid from cellobiose, DLarabinose, D-fructose, L-fucose, D-galactose, D-glucose, maltose, D-mannose, L-rhamnose, D-ribose, D-tagatose, turanose, D-xylose, D-adonitol, erythritol, glycerol, methyl $\beta$-D-xylopyranoside, $N$-acetylglucosamine, aesculin and salicin, but not from D-fucose, gentiobiose, lactose, Dlyxose, melezitose, melibiose, raffinose, L-sorbose, starch, sucrose, trehalose, L-xylose, DL-arabitol, dulcitol, inositol, D-mannitol, D-sorbitol, xylitol, amygdalin, arbutin, glycogen, inulin, methyl $\alpha$-D-mannopyranoside, methyl $\alpha$-Dglucopyranoside, potassium 5-ketogluconate, potassium 2ketogluconate or potassium gluconate. The DNA G $+\mathrm{C}$ content of the type strain is $68.3 \mathrm{~mol} \%$.

The type strain is YIM $93306^{\mathrm{T}}\left(=\mathrm{DSM} 21368^{\mathrm{T}}=\mathrm{KCTC}\right.$ $19413^{\mathrm{T}}=$ CCTCC AB $208069^{\mathrm{T}}$ ), isolated from a salt lake in Xinjiang province, north-west China.

\section{Acknowledgements}

This research was supported by the National Basic Research Program of China (2010CB833800), National Natural Science Foundation of China (30860002, 30870005 and U0932601), Key Project of International Cooperation (2007DFB31620), the 973 Pre-research Program of China (2008CB417214), Yunnan Provincial International Cooperative Program (2009AC017) and the 21C Frontier Program of Microbial Genomics and Applications from the MEST, Korea.

\section{References}

Austwick, P. K. C. (1958). Cutaneous streptothricosis, mycotic dermatitis and strawberry foot rot and the genus Dermatophilus Van Saceghem. Vet Rev Annot 4, 33-48.

Breed, R. S. (1953). The families developed from Bacteriaceae Cohn with a description of the family Brevibacteriaceae. Rias Commun VI Int Cong Microbiol Roma 1, 10-15.

Cerny, G. (1978). Studies on the aminopeptidase test for the distinction of Gram-negative from Gram-positive bacteria. Appl Microbiol Biotechnol 5, 113-122.

Chun, J., Lee, J.-H., Jung, Y., Kim, M., Kim, S., Kim, B. K. \& Lim, Y. W. (2007). EzTaxon: a web-based tool for the identification of prokaryotes based on $16 \mathrm{~S}$ ribosomal RNA gene sequences. Int J Syst Evol Microbiol 57, 2259-2261. 
Cowan, S. T. \& Steel, K. J. (1965). Manual for the Identification of Medical Bacteria. London: Cambridge University Press.

DSMZ (2001). Catalogue of Strains, 7th edn. Braunschweig: Deutsche Sammlung von Mikroorganismen und Zellkulturen. http://www. dsmz.de/species/murein.htm

Felsenstein, J. (1981). Evolutionary trees from DNA sequences: a maximum likelihood approach. J Mol Evol 17, 368-376.

Felsenstein, J. (1985). Confidence limits on phylogenies: an approach using the bootstrap. Evolution 39, 783-789.

Fitch, W. M. (1971). Toward defining the course of evolution: minimum change for a specific tree topology. Syst Zool 20, 406-416.

Gu, Q., Pasciak, M., Luo, H., Gamian, A., Liu, Z. \& Huang, Y. (2007). Ruania albidiflava gen. nov., sp. nov., a novel member of the suborder Micrococcineae. Int J Syst Evol Microbiol 57, 809-814.

Kimura, M. (1980). A simple method for estimating evolutionary rates of base substitutions through comparative studies of nucleotide sequence. J Mol Evol 16, 111-120.

Leifson, E. (1960). Atlas of Bacterial Flagellation. London: Academic Press.

Li, W. J., Schumann, P., Zhang, Y. Q., Xu, P., Chen, G. Z., Xu, L. H., Stackebrandt, E. \& Jiang, C. L. (2005). Proposal of Yaniaceae fam. nov. and Yania flava sp. nov. and emended description of the genus Yania. Int J Syst Evol Microbiol 55, 1933-1938.

Li, W. J., Xu, P., Schumann, P., Zhang, Y. Q., Pukall, R., Xu, L. H., Stackebrandt, E. \& Jiang, C. L. (2007). Georgenia ruanii sp. nov., a novel actinobacterium isolated from forest soil in Yunnan (China) and emended description of the genus Georgenia. Int J Syst Evol Microbiol 57, 1424-1428.

Li, W. J., Zhi, X. Y. \& Euzéby, J. P. (2008). Proposal of Yaniellaceae fam. nov., Yaniella gen. nov. and Sinobaca gen. nov. as replacements for the illegitimate prokaryotic names Yaniaceae Li et al. 2005, Yania Li et al. 2004, emend $\mathrm{Li}$ et al. 2005, and Sinococcus Li et al. 2006, respectively. Int J Syst Evol Microbiol 58, 525-527.

MacKenzie, S. L. (1987). Gas chromatographic analysis of amino acids as the $N$-heptafluorobutyryl isobutyl esters. J Assoc Off Anal Chem 70, 151-160.

Marmur, J. (1961). A procedure for the isolation of deoxyribonucleic acid from microorganisms. J Mol Biol 3, 208-218.

Mesbah, M., Premachandran, U. \& Whitman, W. B. (1989). Precise measurement of the $\mathrm{G}+\mathrm{C}$ content of deoxyribonucleic acid by highperformance liquid chromatography. Int J Syst Bacteriol 39, 159-167.

Minnikin, D. E., O'Donnell, A. G., Goodfellow, M., Alderson, G., Athalye, M., Schaal, A. \& Parlett, J. H. (1984). An integrated procedure for the extraction of isoprenoid quinones and polar lipids. J Microbiol Methods 2, 233-241.

Park, Y.-H., Suzuki, K., Yim, D.-G., Lee, K. C., Kim, E., Yoon, J., Kim, S., Kho, Y. H., Goodfellow, M. \& Komagata, K. (1993). Suprageneric classification of peptidoglycan group $\mathrm{B}$ actinomycetes by nucleotide sequencing of $5 \mathrm{~S}$ ribosomal RNA. Antonie van Leeuwenhoek 64, 307313.

Pribram, E. (1929). A contribution to the classification of microorganisms. J Bacteriol 18, 361-394.

Saitou, N. \& Nei, M. (1987). The neighbor-joining method: a new method for reconstructing phylogenetic trees. Mol Biol Evol 4, 406425.

Sasser, M. (1990). Identification of bacteria by gas chromatography of cellular fatty acids. USFCC Newsl 20, 16.

Schleifer, K. H. (1985). Analysis of the chemical composition and primary structure of murein. Methods Microbiol 18, 123-156.

Schleifer, K. H. \& Kandler, O. (1972). Peptidoglycan types of bacterial cell walls and their taxonomic implications. Bacteriol Rev 36, 407-477.

Stackebrandt, E. \& Prauser, H. (1991). Assignment of the genera Cellulomonas, Oerskovia, Promicromonospora and Jonesia into Cellulomonadaceae fam. nov. Syst Appl Microbiol 14, 261-265.

Stackebrandt, E. \& Schumann, P. (2000). Description of Bogoriellaceae fam. nov., Dermacoccaceae fam. nov., Rarobacteraceae fam. nov. and Sanguibacteraceae fam. nov. and emendation of some families of the suborder Micrococcineae. Int J Syst Evol Microbiol 50, 1279-1285.

Stackebrandt, E., Rainey, F. A. \& Ward-Rainey, N. L. (1997). Proposal for a new hierarchic classification system, Actinobacteria classis nov. Int J Syst Bacteriol 47, 479-491.

Tamura, K., Dudley, J., Nei, M. \& Kumar, S. (2007). MEGA4: Molecular Evolutionary Genetics Analysis (MEGA) software version 4.0. Mol Biol Evol 24, 1596-1599.

Tang, S. K., Tian, X. P., Zhi, X. Y., Cai, M., Wu, J. Y., Yang, L. L., Xu, L. H. \& Li, W. J. (2008). Haloactinospora alba gen. nov., sp. nov., a halophilic filamentous actinomycete of the family Nocardiopsaceae. Int J Syst Evol Microbiol 58, 2075-2080.

Tang, S. K., Wang, Y., Chen, Y., Lou, K., Cao, L. L., Xu, L. H. \& Li, W.-J. (2009). Zhihengliuella alba sp. nov., and emended description of the genus Zhihengliuella. Int J Syst Evol Microbiol 59, 2025-2031.

Zhi, X. Y., Li, W. J. \& Stackebrandt, E. (2009). An update of the structure and 16S rRNA gene sequence-based definition of higher ranks of the class Actinobacteria, with the proposal of two new suborders and four new families and emended descriptions of the existing higher taxa. Int J Syst Evol Microbiol 59, 589-608. 